\title{
ZNAČAJ ELEKTRONIČKE KOMUNIKACIJE U SUDSKIM POSTUPCIMA S POSEBNIM OSVRTOM NA ZEMLJIŠNOKNJIŽNE POSTUPKE
}

Izv. prof. dr. sc Dinka Šago

Izv. prof. dr. sc. Marija Boban

\author{
UDK.: 349.418:004.3/.4 \\ https://doi.org/10.30925/zpfsr.41.1.15 \\ Ur.: 7. siječnja 2020. \\ Pr.: 17. veljače 2020. \\ Pregledni rad
}

\section{Sažetak}

U članku autorice obrađuju temu uporabe informacijsko-komunikacijskih tehnologija i elektroničke komunikacije u sudskim postupcima dajući pregled postojećega zakonodavnog okvira te analizirajući njihov utjecaj na sve veći opseg elektroničkog načina poslovanja. Uvođenje elektroničke obrade podataka u zemljišnoknjižni sustav vrlo je zahtjevan proces ne samo u financijskom, sigurnosnom i tehničkom, nego i u pravnom uređenju postupka elektronifikacije $i$ vođenju zemljišnih knjiga u elektroničkom obliku. U radu su iznesene najvažnije novine koje je donio Zakon o zemljišnim knjigama iz 2019. godine u pogledu elektroničkog poslovanja zemljišnoknjižne službe, kao i pregled odredaba novoga Pravilnika o elektroničkom poslovanju korisnika i ovlaštenih korisnika sustava zemljišnih knjiga. Elektroničko vođenje zemljišnoknjižnih podataka, a posebno pravila o neograničenom uvidu u zemljišnoknjižne podatke putem mrežnih komunikacija, otvaraju niz pitanja uspostave optimalne ravnoteže u zaštiti određenih interesa $i$ prava, a posebno zaštite podataka i osobnih podataka građana. Neograničeni uvid u zemljišnoknjižne podatke doprinosi većoj sigurnosti pravnog prometa, zaštiti povjerenja i većoj zaštiti upisanih nositelja knjižnih prava. S druge strane, otvara važna pitanja povezana $S$ Ustavom zajamčene zaštite osobnih podataka nositelja knjižnih prava.

Ključne riječi: baza zemljišnih podataka; elektronička komunikacija; EOP zemljišna knjiga; informacijska sigurnost; zajednički informacijski sustav.

* Dr. sc. Dinka Šago, izvanredna profesorica, Pravni fakultet Sveučilišta u Splitu; dinka.sago@, pravst.hr.

** Dr. sc. Marija Boban, izvanredna profesorica, Pravni fakultet Sveučilišta u Splitu; marija. boban@pravst.hr. 


\section{1. $U V O D$}

U posljednjih nekoliko godina uložen je veliki napor u razvoj i poboljšanje informacijskih sustava u pravosuđu koji omogućavaju lakše prikupljanje, dostupnost i obradu podataka čime se uspostavlja standardizacija pravosudnog sustava i osigurava pravna sigurnost građana. Novela Zakona o parničnom postupku iz 2019. godine (dalje u tekstu: ZPP 2019.) ${ }^{1}$ čini iskorak predlažući uređenje dostave u skladu s novim mogućnostima i obvezama elektroničke komunikacije. ${ }^{2}$ Zakonodavac uvodi mogućnost da stranke međusobno upućuju pismena elektroničkim putem u svim vrstama postupka, a sve u skladu s pravilima prema kojima obveznici komuniciranja sa sudom putem elektroničke komunikacije postaju državna tijela, odvjetnici, javni bilježnici, sudski vještaci, sudski procjenitelji, sudski tumači, stečajni upravitelji i pravne osobe. ${ }^{3}$

Od 2. studenoga 2015. godine zemljišnoknjižni izvadak sa svojstvom javne isprave može se izdati putem osobnog korisničkog pretinca u sustavu e-Građani ili ga mogu izdati javni bilježnici i odvjetnici. ${ }^{4}$ Od 15. ožujka 2017. godine omogućeno je elektroničko podnošenje prijedloga za upis u zemljišne knjige čime se ubrzava postupak upisa, jamči se veća sigurnost i građanima se olakšava proces upisa. ${ }^{5}$

Novi Zakon o zemljišnim knjigama $2019 .{ }^{6}$ donio je i neke nove institute od kojih je većina usmjerena na elektroničko poslovanje zemljišnoknjižne službe. Neki od njih rezultat su problema na koje su ukazivali praktičari pa su se ovdje našli kao zakonodavno rješenje usmjereno protiv različitih postupanja sudova. Namjera je zakonodavca bila usmjerena ponajprije na zaštitu prava vlasništva i drugih stvarnih prava na nekretninama te na pojednostavljenje i ubrzavanje postupka. Koliko je ZZK 2019. u tome uspio, pokazat će tek dugotrajnija primjena u praksi. ${ }^{7}$

\section{DIGITALIZACIJA ZEMLJIŠNOKNJIŽNOG SUSTAVA}

Jedan od razloga zbog kojih je donesen ZZK 2019. uvjetovan je provedbom Reforme zemljišnih knjiga i katastra koja u svom sadržaju obuhvaća nekoliko

1 Zakon o izmjenama i dopunama Zakona o parničnom postupku, Narodne novine, br. 70/19.

2 Dinka Šago i Marija Boban, „Neki aspekti novina u elektroničkoj komunikaciji pred sudovima”, u: Zbornik radova s V. međunarodnog savjetovanja Aktualnosti građanskog procesnog pravanacionalna i usporedna pravnoteorijska i praktična dostignuća, ur. Šago, Dinka, et al. (Split: Pravni fakultet, 2019.), 471-497.

3 Odluka o dopuni odluke o obveznim sudionicima elektroničke komunikacije pred trgovačkim sudovima, Ministarstvo pravosuđa, 14. ožujka 2019. pristup 9. prosinca 2019., https:// pravosudje.gov.hr> UserDocsImages dokumenti>.

4 Uvid u sustav „Uređena zemlja - ZIS (Zajednički informacijski sustav zemljišnih knjiga i katastra)“, pristup 8. prosinca 2019., https://oss.uredjenazemlja.hr/public/index.jsp.

5 Marina Turković, „E-upis u zemljišne knjige putem javnih bilježnika”, pristup 21. prosinca 2019., http://www.iusinfo.hr/DailyContent/Topical.aspx?id=30288.

6 Zakon o zemljišnim knjigama, Narodne novine, br. 63/19. (dalje u tekstu: ZZK 2019).

7 Ana-Marija Končić, Novi Zakon o zemljišnim knjigama - već otvorena pitanja, pristup 21. prosinca 2019., http://www.iusinfo.hr/Article/Content.aspx?SOPI=CLN20V01D2019 B1327\&Doc $=$ CLANCI_HR. 
komponenti: 1. prenijeti ručno vođene zemljišne knjige u digitalnu formu, 2 . postaviti Bazu zemljišnoknjižnih podataka (dalje u tekstu: BZP), odnosno Zajednički informacijski sustav koji bi povezao BZP i Bazu digitalnih katastarskih planova te 3 . uskladiti katastarske i zemljišnoknjižne podatke na razini cijele države.

Prednosti BZP-a prvenstveno se sastoje u potpunoj sigurnosti da su podatci zemljišne knjige i katastarskog operata usklađeni jer su jedinstveni. Nema dvostruke provedbe, katastar provodi u listu A, a zemljišnoknjižni odjel u A II., B i C. Nema izvatka iz zk. ul. i posjedovnog lista već samo izvadak iz BZP-a, koji mogu izdati oba tijela, ali i ovlašteni korisnici, te se mogu izdati putem sustava e-Građani. Građanima država članica EU-a / Europskog gospodarskog prostora (dalje u tekstu: EU/EGP) 1. listopada 2019. godine omogućen je pristup javnim elektroničkim uslugama iz područja zemljišnih knjiga, a koje pruža Ministarstvo pravosuđa unutar sustava e-Građani. U pristupu se koriste nacionalne vjerodajnice, odnosno sredstva za elektroničku identifikaciju izdanu u EU/EGP, uporabom nadograđenog Nacionalnog sustava autentifikacije za korištenje i upravljanje elektroničkim identitetima. Omogućena je funkcionalnost uvida u javne podatke zemljišnih knjiga - pregled glavne knjige, pregled knjige položenih ugovora, status zemljišnoknjižnih predmeta te izdavanje službenih zemljišnoknjižnih izvadaka. Takvom nadogradnjom One stop shopa (OSS) zemljišnih knjiga omogućeni su ravnopravni uvjeti i funkcionalnosti sustava za građane EU/EGP kao i za građane Republike Hrvatske (dalje u tekstu: $\mathrm{RH}){ }^{8}$

Prijenosom ručno vođenih zemljišnih knjiga $u$ digitalnu formu i njihovim objavljivanjem na mrežnim stranicama omogućeno je iznimno brzo i jasno saznanje o stanju nekretnina, a povezivanjem središnjeg servera s elektroničkom pisarnicom sudova te njihovim povezivanjem na internet ubrzani su procesi protoka informacija između davatelja i korisnika usluga. ${ }^{9}$

Provedbeni propisi koji su na snazi u trenutku stupanja na snagu ZZK 2019. ako nisu u suprotnosti s odredbama ZZK 2019., primjenjivat će se dok nadležni ministar ne donese propise za provedbu ZZK 2019. Tako je 8. studenog 2019. objavljen Pravilnik o elektroničkom poslovanju korisnika i ovlaštenih korisnika sustava zemljišnih knjiga ${ }^{10}$ koji je stupio na snagu 16. studenog 2019. godine. Njegovim stupanjem na snagu prestaje vrijediti Pravilnik o tehničkim i drugim uvjetima elektroničkog poslovanja u zemljišnim knjigama. ${ }^{11}$

8 Nadogradnja je provedena u sklopu projekta „ePIC - Electronic Public Identification Croatia”, koji se sufinancira se iz programa CEF - Connecting Europe Facility - Telecom (Instrument za povezivanje Europe-Telekom) u iznosu od $75 \%$ te se provodi od 2. svibnja 2018. do 31. prosinca 2019. godine. Ministarstvo pravosuđa - službene stranice, pristup 17. prosinca 2019., https:// pravosudje.gov.hr/vijesti/projekt-epic-electronic-public-identification-croatia-21403/21403.

9 Arkadiusz Wudarski i Tatjana Josipović, „Kompjutorizacija u poljskom i hrvatskom pravu”, Zbornik Pravnog fakulteta u Zagrebu 65, br. 1 (2015): 5-54.

10 Pravilnik o elektroničkom poslovanju korisnika i ovlaštenih korisnika sustava zemljišnih knjiga, Narodne novine, br. 108/19.

11 Pravilnik o tehničkim i drugim uvjetima elektroničkog poslovanja u zemljišnim knjigama, Narodne novine, br. 119/15., 23/17- i 106/18. O Pravilniku o tehničkim i drugim uvjetima elektroničkog poslovanja u zemljišnim knjigama vidi i Jozo Čizmić, Dinka Šago i Blanka Kačer, Osnove zemljišnoknjižnog prava (Maribor: University of Maribor Press, 2018.): 393-397. 


\subsection{Digitalizacija и ZZK 2019}

Na temelju čl. 6.ZZK 2019. zemljišne knjige vode se elektronički, u Zajedničkom informacijskom sustavu zemljišnih knjiga i katastra. Riječ je o informacijskom sustavu u kojem se pohranjuju, održavaju i vode svi podatci zemljišnih knjiga i katastra. Usklađeni podatci zemljišne knjige i katastra vode se u BZP-u unutar Zajedničkog informacijskog sustava. Sukladno sa ZZK-om, u BZP-u podatke o imenu katastarske općine, broju katastarske čestice, adresi katastarske čestice, obliku, površini, izgrađenosti i načinu uporabe katastarske čestice vodi središnje tijelo državne uprave nadležno za poslove državne izmjere i katastara nekretnina, a sudovi vode podatke o nositeljima knjižnih prava, pravnim činjenicama i osobnim odnosima.

Rješenja kojima je odlučeno u zemljišnoknjižnim postupcima pohranjuju se u zbirku rješenja. Zbirka zemljišnoknjižnih rješenja vodi se u elektroničkom obliku, a uređuje se zajednički za sve glavne knjige koje se vode kod jednog suda (čl. 31. ZZK 2019.).

\subsubsection{Elektronički $Z$ spis}

Ispunjavanjem tehničkih preduvjeta ministar pravosuđa donosi odluku da se u određenom sudu spis vodi u elektroničkom obliku. U sudu za koji je donesena navedena odluka, a prijedlog nije dostavljen elektroničkim putem, prijedlog zajedno sa svim prilozima službenik će prenijeti u elektronički oblik. Svi naknadno zaprimljeni podnesci i prilozi u pisanom obliku, za spise koji se vode elektronički, prenijet će se u elektronički oblik.

Sve isprave koje su zaprimljene u pisanom obliku vratit će se predlagatelju (čl. 107. ZZK 2019.). U nekim sudovima još nije završio postupak prijepisa i verifikacije uložaka. U tom smislu čl. 14. st. 1. ZZK-a 2019. propisuje obvezu prijenosa u elektronički oblik i pohranu u Zajednički informacijski sustav. Ručno vođene glavne knjige zatvorene nakon pohranjivanja u Zajednički informacijski sustav trajno se čuvaju i pohranjuju u središnjoj arhivi zemljišnih knjiga (čl. 14. st. 3. ZZK 2019.). Svrha pohrane svih skeniranih ručno vođenih zemljišnih knjiga je njihovo očuvanje kao povijesne građe.

Isprave iz ručno vođene zbirke isprava se na zahtjev, radi njihova daljnjeg korištenja, prenose u elektronički oblik i pohranjuju u elektroničku zbirku isprava (čl. 14. st. 2. ZZK 2019.). Ministar pravosuđa donosi odluku o tome kada će pojedini sud početi voditi isključivo elektroničku zbirku isprava. Po donošenju odluke, sve ulazne isprave će se skenirati i pohranjivati u elektroničku zbirku isprava. Najavljuje se i da će se sve zbirke isprava u RH pohraniti u središnjoj arhivi zemljišnih knjiga, s tim da one neće biti prethodno skenirane. Takve će se isprave skenirati po zahtjevu i slati sudu koji je tražio presliku ili ispis isprave za potrebe stranke ili suda. Ministar donosi i odluku o tome kada će određeni sud $\mathrm{Z}$ spise početi voditi u isključivo elektroničkom obliku. To znači da će se osim isprava koje se pohranjuju u elektroničkom obliku, skenirati svi prijedlozi i prilozi predani sudu neposredno. Kada zemljišnoknjižni upis određuje drugi sud, povjerenik suda ili drugo nadležno tijelo, odluka koja je temelj za upis dostavlja se zemljišnoknjižnom sudu isključivo elektroničkim putem, kada su 
za to ispunjeni tehnički uvjeti. Obveza podnošenja prijedloga elektroničkim putem posebno je propisana za nadležno državno odvjetništvo kao ovlaštenog korisnika informacijskog sustava. Sva zemljišnoknjižna rješenja (bilo da ih je donio ovlašteni referent, savjetnik ili sudac) moraju biti digitalno potpisana jer se ustrojava zbirka zemljišnoknjižnih rješenja koja se vodi isključivo u elektroničkom obliku. Čim se ostvare tehnički uvjeti, otprema pošte obavljat će se elektronički, odnosno e-otpremom za sve osobe kojima će takva dostava programski biti moguća. Dostava elektroničkim putem posebno je propisana za pravne osobe, kao i za sve slučajeve kada je prijedlog podnesen elektroničkim putem. Ažuriranje osobnih podataka (adrese, prezimena i sl.) provodi se automatski.

Preduvjet za to je da osoba ima upisan OIB i da to bude strukturiran podatak. $\mathrm{U}$ tom se smislu nadograđuje programsko rješenje Zajedničkog informacijskog sustava. Kad se u elektronički vođenom javnom registru provede promjena podataka o prebivalištu, sjedištu, imenu, prezimenu ili nazivu osobe koja je u zemljišnoj knjizi upisana s osobnim identifikacijskim brojem, taj će se podatak preuzeti elektroničkim putem i promjenu će provesti elektronički sustav u primjeni u poslovanju suda (čl. 127. st. 3. ZZK 2019.). Kad zemljišnoknjižni upis određuje drugi sud, povjerenik suda ili drugo nadležno tijelo, odluku, koja je temelj za upis, nadležno će tijelo dostaviti po službenoj dužnosti elektroničkim putem (čl. 106. ZZK 2019.).

\subsubsection{Pravo na pristup informacijama}

Pravo na pristup i pretraživanje podataka zemljišne knjige za sve katastarske općine po nazivu/imenu nositelja knjižnih prava ili osobnom identifikacijskom broju imaju tijela sudbene vlasti i nadležno državno odvjetništvo kada je to potrebno u pripremi ili vođenju određenog sudskog ili upravnog postupka (čl 28. st. 1. ZZK 2019.). Pravo na pristup i pretraživanje podataka ima Ministarstvo financija, Porezna uprava neposredno pri obavljanju poslova iz svoje nadležnosti, a ostala javnopravna tijela na temelju odluke ministra nadležnog za poslove pravosuđa kada im je to potrebno za obavljanje poslova iz njihove nadležnosti.

Pravo na pristup i pretraživanje podataka dopustit će nadležni sud osobi koja učini vjerojatnim pravni interes. Način pristupa, ovlasti i odgovornosti osoba koje ostvaruju pravo na pristup i pretraživanje uredit će posebnim pravilnikom koji će donijeti ministar pravosuđa. Na temelju ZZK-a 2019. javni bilježnici i odvjetnici ovlašteni su korisnici informacijskog sustava u primjeni u poslovanju suda te mogu na zahtjev stranke izdavati zemljišnoknjižne izvatke. ${ }^{12}$ Hrvatska javnobilježnička komora ističe dva razloga zbog kojih javni bilježnici i odvjetnici do sada nisu rasteretili sudove izdavanja z. k. izvadaka. ${ }^{13}$ Prvi i osnovni razlog je da su veći troškovi za stranke ako izvadak izdaju javni bilježnici i odvjetnici. U tom smislu predlažu ukidanje ili smanjivanje sudske pristojbe za slučaj kada javni bilježnici i odvjetnici, kao ovlašteni korisnici sustava, na zahtjev stranke izdaju zemljišnoknjižne izvatke. Smatraju da će

12 Aleksandra Maganić, „Javni bilježnik u elektroničkom pravnom prometu“, Zbornik radova Pravnog fakulteta u Zagrebu 63, br. 2 (2013): 383-431.

13 E-savjetovanje, pristup 20. prosinca 2019., https://esavjetovanja.gov.hr/Econ/MainScreen? EntityId=9639. 
se puno rasterećenje postići tek ako izdavanja z. k. izvatka na sudu bude skuplje nego kod javnih bilježnika, odnosno odvjetnika. Isto tako javni bilježnici trenutačno mogu pristupiti i pretraživati podatke zemljišnih knjiga za sve katastarske općine jedino prema katastarskoj čestici i broju zemljišnoknjižnog uloška. Kada stranka ne zna te podatke javnom bilježniku je otežano ili ne može izvršiti pretragu, pa stoga niti izdati traženi z. k. izvadak. ${ }^{14}$

\subsubsection{Podnošenje prijedloga}

Članak 105. ZZK 2019. propisuje način podnošenja prijedloga vodeći računa o digitalizaciji sustava. Prijedlog se podnosi elektronički, putem javnog bilježnika i odvjetnika, kao ovlaštenih korisnika informacijskog sustava u primjeni u poslovanju suda, putem sustava e-Građani, u pisanom obliku neposredno ili putem ovlaštenog pružatelja poštanskih usluga. Time se osigurava pravna sigurnost u poslovanju $\mathrm{s}$ nekretninama jer je plombiranje prijedloga u zemljišnoj knjizi moguće odmah po potpisivanju ugovora o kupoprodaji nekretnine, čime se skraćuje vrijeme od trenutka kupoprodaje do podnošenja prijedloga upisa u zemljišnu knjigu. Ostale prednosti elektroničkog podnošenja prijedloga su: omogućava se brže i jednostavnije poslovanje u zemljišnim knjigama te se smanjuje broj nepotpunih prijedloga za upis u zemljišnu knjigu, a time se smanjuje i broj odbijenih i odbačenih prijedloga za upis.

NovelomZZK 2019. uvedena je odredba kojom je propisano kad zemljišnoknjižni upis određuje drugi sud, povjerenik suda_ili drugo nadležno tijelo, odluku koja je temelj za upis nadležno tijelo dostavit će po službenoj dužnosti elektroničkim putem (čl. 106. ZZK 2019.). Trenutačno elektroničkim putem odluke dostavlja nadležno državno odvjetništvo, dok se za javne bilježnike kao povjerenike suda još nadograđuje program. Za ostala tijela i sudove još nije postavljen program niti provedena edukacija, pa će se ova odredba početi primjenjivati tek po ispunjavanju tehničkih uvjeta. Sudovi će se povezati putem aplikacije što će omogućiti izravnu elektroničku komunikaciju između različitih sudskih odjela.

Ako je prijedlog podnesen elektroničkim putem, pismena suda dostavit će se predlagatelju elektronički, a ostalim strankama elektroničkim putem ako su ispunjeni tehnički uvjeti. Dostava se smatra izvršenom u trenutku zaprimanja pismena na poslužitelju primatelja (čl. 137. st. 7. ZZK 2019.). Oglasna ploča vodi se elektronički (čl. 137. st. 8. ZZK 2019.). Dostava se neće izvršiti elektronički predlagatelju ako je prijedlog podnesen elektronički putem javnog bilježnika, osim ako ga je predlagatelj opunomoćio za primanje pismena ili je dostavio punomoć. Samo jedna vrsta rješenje otprema se isključivo pisanim putem. Riječ je o predmetu zabilježbe prvenstvenog reda radi namjeravanog otuđenja ili opterećenja nekretnine koji je propisan čl. 77. do 82. ZZK-a 2019. ${ }^{15}$

14 O javnobilježničkoj nadležnosti vidi Ivana Vrcić, „Mogući aspekti zaštite stranaka u pravnom prometu nekretnina širenjem javnobilježničke nadležnosti“, Javni bilježnik br. 43 (2016): 99105.

15 Ana-Marija Končić, Novi Zakon o zemljišnim knjigama, pristup 17. prosinca 2019., http:// www.iusinfo.hr/Article/Content.aspx?SOPI=CLN20V01D2019B1306\&Doc=CLANCI_HR. 


\subsubsection{Odgovornost države za štetu}

Republika Hrvatska objektivno odgovara za štete prouzročene pogreškama u vođenju zemljišne knjige. Odgovornost RH za štetu isključena je kad je šteta prouzročena neotklonjivim događajem, ali ona postoji ako je šteta prouzročena manom ili nedostatkom računalnoga programa ili zakazivanjem računala. Tim se odredbama ne dira u odgovornost sudaca i službenika za štetu koja nastane nepravilnim, odnosno nezakonitim radom sudaca, odnosno službenika, a čija je odgovornost propisana drugim zakonima koji reguliraju odgovornost sudaca, odnosno sudskih službenika (čl. 9. ZZK 2019.). ${ }^{16}$

\subsubsection{Pojedinačno preoblikovanje}

Pojedinačno preoblikovanje zemljišnih knjiga u BZP provodi se za jednu ili više katastarskih čestica kada su podatci iz zemljišne knjige i podatci iz katastarskog operata istovjetni u odnosu na broj, površinu i izgrađenost katastarske čestice te $\mathrm{s}$ upisanim nositeljima prava na nekretninama (čl. 217. ZZK 2019.). ${ }^{17}$

Ministar pravosuđa, uz prethodnu suglasnost čelnika središnjeg tijela državne uprave mjerodavne za katastar, odredit će odlukom početak pojedinačnog preoblikovanja zemljišnih knjiga za određeni sud. Odluka se objavljuje na e-Oglasnoj ploči, oglasnoj ploči nadležnog suda i tijela nadležnog za katastar, na mrežnim stranicama ministarstva nadležnog za poslove pravosuđa i jedinice lokalne samouprave ili na drugi prikladan način. Odluka sadrži: naziv suda, zemljišnoknjižnog odjela i tijela nadležnog za katastar koji provode postupak, ime katastarske općine u kojoj se provodi postupak te dan početka postupka (čl. 218. ZZK 2019). ${ }^{18}$

Da bi se do uspostave BZP-a omogućilo vođenje zemljišnoknjižnih podataka u elektroničkom obliku, Pravilnik o unutarnjem ustroju, vođenju zemljišnih knjiga i obavljanju drugih poslova u zemljišnoknjižnim odjelima sudova (Zemljišnoknjižni poslovnik) ${ }^{19}$ (dalje u tekstu: ZP) posebno uređuje pretpostavke za preoblikovanje postojećih podataka iz ručno vođene zemljišne knjige u elektronički oblik (čl. 159.161. ZP). Postupak preoblikovanja važećih podataka iz ručno vođene zemljišne knjige u elektronički oblik dopušten je samo korištenjem standardne programske podrške Ministarstva pravosuđa $\mathrm{i}$ to samo na temelju odluke tog ministarstva o početku preoblikovanja za pojedini sud. Preoblikovanje se provodi:

a) sporadično - po podnescima zaprimljenim nakon donošenja odluke o preoblikovanju u elektronički oblik i to tako da se zemljišnoknjižni ulošci i sve promjene unose $\mathrm{u}$ računalo $\mathrm{i}$ nadalje vode isključivo $\mathrm{u}$ elektroničkom obliku po

16 Damir Kontrec, „Preoblikovanje zemljišne knjige”, u: Osnivanje, obnavljanje, dopunjavanje $i$ preoblikovanje zemljišne knjige, ur. Jerko Slovinić (Zagreb: Novi informator, 2005.), 156.

17 Tatjana Josipović, „Novine u uređenju zemljišnih knjiga”, Pravo u gospodarstvu 35, br. 7-8 (1996): 690-694.

18 Bruno Ružička, „Stanje digitalne zemljišne knjige realnost ili tlapnja“, Pravo u gospodarstvu 57, br. 1 (2018): 145-163.

19 Pravilnik o unutarnjem ustroju, vođenju zemljišnih knjiga i obavljanju drugih poslova u zemljišnoknjižnim odjelima sudova, Zemljišnoknjižni poslovnik, Narodne novine, br. 81/97., 109/02., 123/02., 153/02., 14/05. i 60/10. 
službenoj dužnosti i

b) sustavno - sustavnim prenošenjem važećih podataka svih zemljišnoknjižnih uložaka pojedine katastarske općine iz ručno vođene zemljišne knjige u računalo. ${ }^{20}$

Prije donošenja odluke provodi se postupak analize usklađenosti podataka o katastarskim česticama. Katastarske čestice svrstavaju se u dvije grupe:

1. katastarske čestice istovjetne u odnosu na podatke zemljišne knjige $\mathrm{i}$ katastarskog operata o broju i površini, a koje zemljišnoknjižni referent mora provjeriti i potvrditi prije prijenosa u BZP i

2. katastarske čestice čiji se podatci u zemljišnoj knjizi i katastarskom operatu razlikuju u odnosu na podatke o broju i površini katastarske čestice te nisu podobne za preoblikovanje bez provedbe prethodnog postupka usklađivanja (čl. 219. ZZK 2019.).

Postupak provodi ovlašteni zemljišnoknjižni referent ili zemljišnoknjižni referent pod nadzorom ovlaštenoga zemljišnoknjižnog referenta. Broj zemljišnoknjižnog uloška podobnog za pojedinačno preoblikovanje ostaje isti i u BZP-u (čl. 221. ZZK 2019.).

Pri preoblikovanju zemljišne knjige prenijet će se u BZP svi upisi koji se odnose na podatke o nositeljima knjižnih prava, pravnim činjenicama i osobnim odnosima, a s onim sadržajem i u onom obliku koji odgovara pravilima o vođenju glavne knjige. Iznimno, neće se prenijeti:

- upisi čiji sadržaj ne može biti predmetom zemljišnoknjižnoga upisa te

- upisi koji se s velikom vjerojatnošću mogu smatrati bespredmetnima jer pravo koje im je predmetom ili na koje se oni odnose ne postoji ili se trajno ne može faktično izvršavati ili je zastarjelo ili je to hipoteka od čijega je upisa proteklo najmanje 30 godina, a vrijednost njome osigurane tražbine očito je neznatna.

Kada je na temelju posebnoga zakona neko knjižno pravo zamijenjeno drugim, u BZP će se prema odredbama toga zakona, a ne dirajući u ostale upise, s istim prvenstvenim redom pri prenošenju unijeti to drugo pravo, što se ne smatra osnivanjem novoga prava (čl. 222. ZZK 2019.). ${ }^{21}$

Ako postoje odstupanja u podatcima zemljišne knjige i podatcima katastra za jednu ili više katastarskih čestica u odnosu na izgrađenost, pojedinačno preoblikovanje izvršit će se uz provjeru i potvrdu zemljišnoknjižnog referenta samo ako je podatak o broju zgrada u katastru jednak ili veći u odnosu na podatak o broju zgrada u zemljišnoj knjizi (čl. 223. ZZK 2019.). Kada postoje odstupanja u podatcima o upisanim nositeljima prava u zemljišnoj knjizi i katastarskom operatu, a u zemljišnoj knjizi je upisano etažno vlasništvo, pojedinačno preoblikovanje će se izvršiti, bez obzira na postojeće upise o nositeljima prava u katastarskom operatu. Kada se prijavni list, koji je pregledalo i potvrdilo tijelo nadležno za katastar, provede u zemljišnoj knjizi, katastarske čestice osnovane tim prijavnim listom prenijet će se u BZP, ako su podatci o upisanim nositeljima knjižnih prava u zemljišnoj knjizi istovjetni s podatcima u katastarskom operatu (čl. 224. ZZK 2019.).

Kada je u katastarskom operatu nositelj prava na nekretninama upisan $\mathrm{s}$ različitom adresom od one u zemljišnoj knjizi, odnosno kada je u katastarskom operatu

20 Kontrec, Preoblikovanje zemljišne knjige, 139.

21 Čizmić, Šago i Kačer, Osnove zemljišnoknjižnog prava, 735. 
upisan osobni identifikacijski broj nositelja prava na nekretninama, a u zemljišnoj knjizi nije, a zemljišnoknjižni referent utvrdi da je riječ o istovjetnoj osobi, preuzet će se noviji podatak o adresi, odnosno osobni identifikacijski broj iz katastarskog operata (čl. 225. ZZK 2019.). Ako je postupljeno prema čl. 225. ZZK 2019., stranka može podnijeti prijedlog za ispravak tako da se upis u vlastovnici ili teretovnici vrati na stanje koje je bilo prije postupka pojedinačnog preoblikovanja (čl. 229. ZZK 2019.). Ako se ispravkom dira u knjižna prava trećih koja su bila upisana nakon preoblikovanja zemljišne knjige u BZP, ispravak je dopušten samo ako prijedlog stigne zemljišnoknjižnom sudu u roku od šest mjeseci od dana preoblikovanja u BZP ili se unutar toga roka provede ispravak po službenoj dužnosti. Time se ne dira u mogućnost da se tužbom zahtijeva brisanje prema odredbama ZZK 2019. o brisovnoj tužbi, niti se dira u zaštitu koju uživa pošteni stjecatelj (čl. 230. ZZK 2019.). ${ }^{22}$

Kada jedan zemljišnoknjižni uložak ima više katastarskih čestica, a neke od njih nisu podobne za pojedinačno preoblikovanje, te će se katastarske čestice po službenoj dužnosti otpisati u novi zemljišnoknjižni uložak na način propisan u čl.180. i 181. ZZK 2019., dok će se katastarske čestice u postojećem zemljišnoknjižnom ulošku koje su podobne za pojedinačno preoblikovanje prenijeti u BZP. Za postupak preoblikovanja podobne su samo one katastarske čestice na kojima nema tereta (čl. 226. ZZK 2019.).

Za katastarske čestice iz čl. 219. st. 2. toč. 2., katastarske čestice čiji se podatci u zemljišnoj knjizi i katastarskom operatu razlikuju u odnosu na podatke o broju i površini katastarske čestice te nisu podobne za preoblikovanje bez provedbe prethodnog postupka usklađivanja, postupak pojedinačnog preoblikovanja provodi se tek nakon što se u nekom od postupaka propisanih odredbama ZZK 2019. stanje u zemljišnoj knjizi uskladi sa stanjem u katastarskom operatu (čl. 227. ZZK 2019.).

U trenutku kad se u BZP pohrane upisi katastarske čestice koja je pojedinačno preoblikovana, sud će tu katastarsku česticu po službenoj dužnosti nastaviti voditi kao dio BZP-a (čl. 228. ZZK 2019.).

Ako se pri preoblikovanju u BZP nije postupilo prema pravilima o prenošenju upisa, na prijedlog ili po službenoj dužnosti provest će se ispravci na temelju posebnoga rješenja suda. Isto vrijedi i ako je propušteno prenijeti neki upis. Na zahtjev će se izdati rješenje o brisanju upisa koji je ocijenjen nedopuštenim, a to vrijedi i kad je postupljeno prema čl. 222. st. 3. ZZK 2019. Kada je na temelju posebnoga zakona neko knjižno pravo zamijenjeno drugim, u BZP će se prema odredbama toga zakona, a ne dirajući $u$ ostale upise, $\mathrm{s}$ istim prvenstvenim redom prilikom prenošenja unijeti to drugo.

Zemljišnoknjižni predmeti koji nisu riješeni u trenutku otvaranja BZP-a, kao i zemljišnoknjižni podnesci koji zemljišnoknjižnom sudu stignu u roku iz čl. 228. ZZK 2019. usporedit će se i s knjižnim stanjem u glavnoj knjizi vođenoj prije preoblikovanja. Pokaže li se potreba za ispravkom upisa prenesenih u BZP, odgovarajući će se primijeniti odredbe članaka 229. i 230. ZZK-a 2019.

Zemljišnoknjižni predmeti koji nisu riješeni u trenutku pojedinačnog preoblikovanja u BZP, a odnose se na drugi odjeljak posjedovnice, vlastovnicu

22 Dinka Šago i Zrinka Radić, „Brisovna tužba - zaštita knjižnih prava“, Zbornik Pravnog fakulteta Sveučilišta u Rijeci 38, br. 1 (2017): 475-499. 
i teretovnicu, ne priječe prelazak čestica u BZP. Ako se odnose na prvi odjeljak posjedovnice, potrebno ih je riješiti prije prelaska čestica u BZP (čl. 231. ZZK 2019.). Ovim je odredbama propisan način postupanja sa zemljišnoknjižnim predmetima koji su zaprimljeni prije otvaranja BZP-a, a nisu riješeni u trenutku pojedinačnog preoblikovanja u BZP. Predmeti koji se odnose na prvi odjeljak posjedovnice, moraju biti riješeni prije prelaska čestice u BZP, dok preostali predmeti ne sprječavaju prelazak čestice u BZP. Novinom se ubrzava postupak prelaska u BZP jer se prije prelaska ne moraju riješiti svi ranije zaprimljeni predmeti. ${ }^{23}$ Mislimo da se zanemaruje činjenica da za pravni promet nekretnina nije bitan samo predmet prodaje nego i nositelj knjižnih prava te taj podatak dobiva sporednu ulogu u postupcima osnivanja, obnove ili dopune zemljišne knjige. Smanjuju se uloge zemljišnoknjižnih postupaka u odnosu na upis nekretnine i utvrđivanje nositelja stvarnih prava na nekretnini od uloge koju imaju postupci izmjere katastarskih općina ili njihovih dijelova. Time pravila postupanja za upis nekretnine u katastar nekretnina neće omogućiti stvaranje BZP-a koji je trebao sadržavati pri unosu usklađenih podataka o nekretnini i unos podataka o nositeljima knjižnih prava. ${ }^{24}$

Poslovi osnivanja, obnove i dopune zemljišne knjige, kao i poslovi pojedinačnog preoblikovanja zemljišne knjige u BZP poslovi su od interesa za RH i financiraju se iz sredstava proračuna i (ili) drugih izvora.

\subsection{Pravilnik o elektroničkom poslovanju korisnika i ovlaštenih korisnika sustava zemljišnih knjiga}

Pravilnik uređuje tehničke uvjete, uvjete uporabe i troškove elektroničkog poslovanja u zemljišnim knjigama od strane korisnika i ovlaštenih korisnika informacijskog sustava u primjeni u poslovanju suda. Primjenjuje se na ovlaštene korisnike za izdavanje verificiranih zemljišnoknjižnih izvadaka i podnošenja prijedloga za upis u zemljišnu knjigu elektroničkim putem.

$\mathrm{Na}$ temelju čl. 4. ovlašteni korisnik je javni bilježnik, odvjetnik, a nadležno državno odvjetništvo kada je to potrebno u pripremi ili vođenju određenog sudskog ili upravnog postupka. ${ }^{25}$ Korisnik je fizička osoba koja ima ovlaštenje na pristup putem sustava e-Građani. Administrator sustava je ministarstvo pravosuđa. Pristup zemljišnim knjigama elektroničkim putem ostvaruje se putem Jedinstvenog poslužnog mjesta zemljišnih knjiga i katastra (oss.uredjenazemlja.hr) podsustava Zajedničkog informacijskog sustava zemljišnih knjiga i katastra. Ovlašteni korisnik ostvaruje pristup sustavu izravno putem osobnoga korisničkog računa. Korisnik ostvaruje pristup sustavu putem sustava e-Građani.

23 Obrazloženje nacrta prijedloga Zakona o izmjenama i dopunama Zakona o zemljišnim knjigama, Ministarstvo pravosuđa, Zagreb, 2017., str. 20, pristup 6. prosinca 2019., https:// vlada.gov.hr $>$ UserDocsImages $>$ Sjednice $>2017$.

24 Ljiljana Matuško Antonić, „Novela Zakona o zemljišnim knjigama“, Pravo i porezi br. 12 (2017): 98.

25 Mira Grbac, „Tranzicija javnobilježničke službe - od tradicije do elektronifikacije“, Javni bilježnik br. 43 (2016): 107-112. 


\subsubsection{Dodjela osobnog korisničkog računa}

Za dodjelu osobnog korisničkog računa ovlašteni korisnik podnosi zahtjev administratoru sustava putem Hrvatske odvjetničke komore (dalje u tekstu: HOK), Hrvatske javnobilježničke komore (dalje u tekstu: HJK) i Državnog odvjetništva RH. Zahtjev mora sadržavati: ime, prezime, osobni identifikacijski broj i adresu elektroničke pošte ovlaštenog korisnika. Administrator sustava dužan je u roku od tri dana od primitka zahtjeva ovlaštenom korisniku na adresu elektroničke pošte dostaviti podatke o aktivaciji osobnoga korisničkog računa. Dodjelom osobnoga korisničkog računa ovlaštenom korisniku počinje pravo korištenja osobnoga korisničkog računa. Pravo korištenja osobnoga korisničkog računa prestaje brisanjem iz imenika odvjetnika, imenika javnih bilježnika i razrješenjem zamjenika državnih odvjetnika. O navedenim okolnostima HOK, HJK, odnosno Državno odvjetništvo RH obvezni su u roku tri dana obavijestiti administratora sustava. Administrator sustava dužan je po zaprimljenoj obavijesti u roku tri dana brisati osobni korisnički račun ovlaštenog korisnika.

\subsubsection{Postupak izdavanja zemljišnoknjižnog izvatka}

Postupak izdavanja zemljišnoknjižnog izvatka pokreće se zahtjevom za izdavanjem zemljišnoknjižnog izvatka ili izvatka iz knjige položenih ugovora te unosom podataka o imenu katastarske općine i broju katastarske čestice ili zemljišnoknjižnog uloška. Sustav zaprima zahtjev i omogućuje uvid u zemljišnoknjižni izvadak. Nakon potvrde o plaćanju sudske pristojbe sustav će izdati zemljišnoknjižni izvadak i dostaviti ga u osobni korisnički pretinac sustava. Zemljišnoknjižni izvadak potpisan je aplikativnim certifikatom administratora sustava. Vjerodostojnost zemljišnoknjižnog izvatka utvrđuje se putem otisnutog kontrolnog broja i mrežne stranice, odnosno QR koda (čl. 8. Pravilnika). Dakle, elektronički izdan izvadak sustav ovjerava QR kodom te se kao takav smatra vjerodostojnom ispravom.

Svakom izdanom zemljišnoknjižnom izvatku dodjeljuje se redni broj zahtjeva, datum i vrijeme zaprimanja zahtjeva te naziv suda glavne knjige u sustavu. Podatci o izdanim zemljišnoknjižnim izvadcima čuvaju se u sustavu (čl. 9. Pravilnika). Za izdavanje zemljišnoknjižnog izvatka plaća se sudska pristojba.

\subsubsection{Elektroničko podnošenje prijedloga za upis}

Prijedloge koji su podneseni elektroničkim putem, zemljišnoknjižni odjeli zaprimaju i vode kao elektronički spis (čl. 11. Pravilnika). Takvi prijedlozi moraju biti potpisani kvalificiranim elektroničkim potpisom koji ima jednak pravni učinak kao vlastoručni potpis i otisak pečata, koji je izdao kvalificirani pružatelj usluga. ${ }^{26}$ Uz prijedlog i dopunu se u elektroničkom obliku prilažu svi prilozi koji su u istima naznačeni (čl. 12. st. 1. Pravilnika). S obzirom na to da HJK zajedno s Ministarstvom

26 Goran Milaković, „Elektroničko poslovanje u zemljišnim knjigama“, pristup 19. prosinca 2019., http://www.iusinfo.hr/Article/Content.aspx?SOPI=CLN20V01D2017B1069\&Doc=CLANCI_ HR. 
pravosuđa radi na integraciji informatičkog sustava HJK (e-Notar) s informacijskim sustavom u primjeni u poslovanju suda, a osobito u odnosu na podnošenje prijedloga za upis u zemljišne knjige elektroničkim putem te da bi se prema tehničkoj specifikaciji i u skladu s mogućnostima tehnologije pri podnošenju prijedloga putem mrežnog servisa za potpisivanje samog prijedloga koristio upravo aplikativni certifikat administratora sustava, izrijekom je propisana i mogućnost korištenja takvog elektroničkog potpisa s obzirom na strogo formalnu prirodu zemljišnoknjižnih postupaka. ${ }^{27}$ Time se u potpunosti izbjegla mogućnost tumačenja je li prijedlog potpisan ispravnim elektroničkim potpisom ili ne. ${ }^{28}$

Ako se prijedlog za upis i dopuna prijedloga podnose putem mrežnog servisa, može se elektronički potpisati valjanim certifikatom administratora sustava ovlaštenog korisnika. Pisane priloge dostavljene u izvorniku ili ovjerenom prijepisu, ovlašteni korisnik prenijet će u elektronički oblik te će svaki priloženi dokument potpisati kvalificiranim elektroničkim potpisom (čl. 12. st. 2. Pravilnika).

Pisani prilozi nakon što se prenesu u elektronički oblik vraćaju se predlagatelju, a isprave prenesene u elektronički oblik ovlašteni korisnici čuvat će prema posebnim propisima o odlaganju i čuvanju. Kada se uz prijedlog i dopunu prilažu javnobilježničke isprave ili druge javne isprave koje su već u elektroničkom obliku, one se pri dostavi elektroničkog prijedloga i dopune prijedloga samo potpisuju kvalificiranim elektroničkim potpisom (čl. 12. st. 3. Pravilnika).

Isprave koje ovlašteni korisnici pretvaraju u elektronički oblik se ne čuvaju, budući da ne postoje odredbe o čuvanju isprava. Bilo bi oportuno isto izrijekom propisati odnosno propisati da se isprave vraćaju stranci koja ih je podnijela. Time bi se jasno odredila prava i obveze ovlaštenih korisnika i stranaka koje koriste njihove usluge. Nužno je i istaknuti da isprave koje se pretvaraju u elektronički oblik i podnose se uz prijedlog za upis u zemljišne knjige osim u posjedu stranaka, nalaze u arhivima javnih bilježnika te se čuvaju najmanje tri godine pa do trajno, ovisno o vrsti isprave. Uzimajući u obzir naprijed navedeno, jasno je da pravna sigurnost ne može biti ugrožena time što se isprave vraćaju stranci, jer sud u slučaju potrebe uvijek može pozvati stranke da dostave izvornike isprava, odnosno da se izvrši uvid u arhivu javnog bilježnika.

Prijedlogzaupis podnesen elektroničkimputem smatrase dajezemljišnoknjižnom sudu stigao kada je evidentiran na poslužitelju primatelja na kojem se bilježi dan, mjesec, godina, sat i minuta prispijeća prijedloga (čl. 13. Pravilnika). Navedena odredba uređena je u skladu s čl. 108. st. 2. ZZK-a 2019. Naime, kao vrijeme kada je prijedlog za upis stigao zemljišnoknjižnom sudu utvrđeno je vrijeme evidentirano na poslužitelju primatelja. Pri podnošenju prijedloga elektroničkim putem, sustav vraća korisniku potvrdu o zaprimljenom predmetu na kojoj je ispisan datum i vrijeme (sat, minuta i sekunda) zaprimanja te je naznačeno vrijeme jedino mjerodavno za utvrđivanje reda prvenstva postupanja po zaprimljenim predmetima. Isto se vrijeme

27 E-savjetovanje, pristup 21. prosinca 2019., https://esavjetovanja.gov.hr/Econ/MainScreen? entityId=11534.

28 Marina Turković, „E-upis u zemljišne knjige putem javnih bilježnika”, pristup 21. prosinca 2019., http://www.iusinfo.hr/DailyContent/Topical.aspx?id=30288. 
zaprimanja ispisuje i na prijamnom štambilju i kod neposrednog podnošenja prijedloga sudu, čime su sve stranke u jednakom položaju. ${ }^{29}$

Mišljenja smo da je neprecizno određeno vrijeme koje se smatra vremenom podnošenja prijedloga. Moglo bi se, primjerice, unijeti odredbu o kvalificiranom vremenskom žigu koji povezuje dan i sat podnošenja prijedloga oznakom točnog vremena povezanom s koordiniranim svjetskim vremenom, kao što je to propisano odredbom čl. 5. st. 6. i čl. 11. Pravilnika o elektroničkoj komunikaciji u postupcima pred trgovačkim sudovima. ${ }^{30,31}$ Ovu bi se odredbu moglo i dopuniti unošenjem stavka o obavijesti suda o primitku elektroničkog podneska uz korištenje kvalificiranog vremenskog žiga. Naime, kada odvjetnik kao kvalificirani korisnik prijedlog predaje elektroničkim putem ne zna kada je evidentiran na poslužitelju primatelja. Nasuprot tomu kada neuka stranka na protokolu suda preda prijedlog sud odmah, čini vidljivim dan i vrijeme kada je prijedlog podnesen. Precizno određivanje vremena iznimno je bitno u zemljišnoknjižnim predmetima zbog različitih razloga, primjerice prvenstvenog reda upisa. ${ }^{32}$

\section{SIGURNOSNI ASPEKT ELEKTRONIČKE KOMUNIKACIJE U SUDSKIM POSTUPCIMA}

Kada je riječ o elektroničkoj komunikaciji u sudskim postupcima nužno je ponajprije razmotriti pitanje informacijske sigurnosti, pa samim time i elektroničke komunikacije u građanskim sudskim postupcima. ${ }^{33}$ Ti oblici komunikacije i takav način razmjene podataka u kontekstu građanskih sudskih postupaka mogu se promatrati dvojako. Prvi je aspekt sigurnost i uporaba informacijsko-komunikacijske tehnologije u postupku općenito kao podrške za učinkovitije obavljanje svih poslova suda i upravljanje sudskim spisima. ${ }^{34} \mathrm{U}$ tom je smislu naglasak stavljen na informacijsku sigurnost kao osnovni dio sigurnosti zajedničkog informacijskog sustava zemljišnih knjiga i katastra u RH koji može znatno poboljšati komunikaciju između sudova višeg i nižeg stupnja, pridonijeti ujednačavanju sudske prakse te lakše i brže razmjene

29 E-savjetovanje, pristup 21. prosinca 2019., https://esavjetovanja.gov.hr/Econ/MainScreen? EntityId $=11534$.

30 Pravilnik o elektroničkoj komunikaciji u postupcima pred trgovačkim sudovima, Narodne novine, br. 12/18.

31 Dinka Šago i Marija Boban, „Neki aspekti novina u elektroničkoj komunikaciji pred sudovima”, u: Zbornik radova s $V$. međunarodnog savjetovanja Aktualnosti građanskog procesnog pravanacionalna i usporedna pravnoteorijska i praktična dostignuća, ur. Šago, Dinka, et al. (Split: Pravni fakultet, 2019.), 477-484.

32 Dinka Šago, „Zabilježba prvenstvenog reda u zemljišnim knjigama“, u: Zbornik radova s III. međunarodnog savjetovanja Aktualnosti građanskog procesnog prava - nacionalna $i$ usporedna pravnoteorijska i praktična dostignuća, ur. Dinka Šago et al. (Split: Sveučilište u Splitu, Pravni fakultet, 2017.), 275-297.

33 Agustí Cerrillo Martínez et al., E-Justice: Using Information Communication Technologies in the Court System (Hershey, New York: IGI Global, 2008.), 21.

34 Paul Shaw, Managing Legal and Security Risks in Computers and Communications (Boston: Butterworth-Heinemann, 1998.), 160. 
službenih podataka. ${ }^{35}$ Drugi se aspekt odnosi na elektroničko poslovanje sigurnost elektroničke komunikacije korisnika i ovlaštenih korisnika sustava zemljišnih knjiga. Kako se danas u velikom opsegu pravni poslovi odvijaju elektroničkim putem te elektronički oblik dokumentacije postupno zamjenjuje papirnati, kada dođe do prijepora, nužno je omogućiti sudovima da na primjeren način mogu svim sudionicima pružiti učinkovitu pravnu zaštitu. ${ }^{36}$

\subsection{Pravni okvir informacijske sigurnosti i elektroničkih komunikacija u Republici Hrvatskoj}

Postojeća zakonska regulativa koja uređuje pitanja informacijske sigurnosti ponajprije je usmjerena definiranju pojma informacijske sigurnosti, mjera i standarda informacijske sigurnosti, područja informacijske sigurnosti te definiranju nadležnih tijela za donošenje, provođenje i nadzor mjera i standarda informacijske sigurnosti. ${ }^{37}$

Sigurnost u elektroničkoj komunikaciji definirana je nizom propisa, od kojih ćemo u nastavku teksta obraditi Zakon o informacijskoj sigurnosti, ${ }^{38}$ Zakon o tajnosti podataka $^{39}$ i Zakon o elektroničkim komunikacijama. ${ }^{40}$

Prema ZIS-u, termin informacijske sigurnosti definira se kao stanje povjerljivosti, cjelovitosti i raspoloživosti podatka, koje se postiže primjenom propisanih mjera i standarda informacijskesigurnostite organizacijskom podrškom za poslove planiranja, provedbe, provjere $i$ dorade mjera $i$ standarda (čl. 2. ZIS). ZIS se primjenjuje na državna tijela, tijela jedinica lokalne i područne (regionalne) samouprave te na pravne osobe s javnim ovlastima koje u svojem djelokrugu upotrebljavaju klasificirane i neklasificirane podatke (čl. 1 st. 2. ZIS). Primjenjuje se i na pravne i fizičke osobe koje ostvaruju pristup ili postupaju s klasificiranim podatcima i neklasificiranim podacima (čl. 1. st. 3. ZIS).

Kada postoji interes javnosti, vlasnik podatka dužan je ocijeniti razmjernost između prava na pristup informacijama i zaštite vrijednosti te odlučiti o zadržavanju stupnja tajnosti, promjeni stupnja tajnosti, deklasifikaciji ili oslobađanju od obveze čuvanja tajnosti podatka. Prije donošenja odluke vlasnik je podatka obvezan zatražiti mišljenje Ureda Vijeća za nacionalnu sigurnost (čl. 16. ZTP). ${ }^{41}$

35 Jeffrey Matsuura, Security, Rights, and Liabiities in E-Commerce (Boston: Artech House, 2001.), 125.

36 Miklós Kengyel i Zoltán Nemessányi, Electronic Technology and Civil Procedure: New Paths to Justice from Around the World (Hague: Springer Science \& Business Media, 2012.), 3.

37 Council of Europe, Information Technology and Law: Linking Systems and Their Users: Modern Communication Techniques in the Legal Field: Proceedings (Strasbourg: Council of Europe, 2001.).

38 Zakon o informacijskoj sigurnosti, Narodne novine, br. 79/07. (dalje u tekstu: ZIS).

39 Zakon o tajnosti podataka, Narodne novine, br. 79/07., 86/12. (dalje u tekstu: ZTP).

40 Zakon o elektroničkim komunikacijama, Narodne novine, br. 73/08., 90/11., 133/12., 80/13., 71/14., 72/17. (dalje u tekstu: ZEK).

41 Jozo Čizmić, Marija Boban i Dragan Zlatović, Nove tehnologije, intelektualno vlasništvo $i$ informacijska sigurnost (Split: Pravni fakultet Sveučilišta, 2016.), 205. 


\subsection{Elektroničko poslovanje i elektronička komunikacija korisnika $i$ ovlaštenih korisnika sustava zemljišnih knjiga}

Elektroničko poslovanje i elektroničke komunikacija u ZIS-u uređuju se Pravilnikom o elektroničkom poslovanju korisnika i ovlaštenih korisnika sustava zemljišnih knjiga. Temeljna je postavka elektroničkog poslovanja povećanje transparentnosti i vidljivosti zemljišnih knjiga. No, ona istodobno otvara i pitanje sigurnosti i podataka i osobnih podataka građana koji su uneseni i sastavni su dio elektroničke evidencije koja je dostupna putem intraneta (na zahtjev zaposlenika), a i javnosti putem internetskih tehnologija. ${ }^{42}$

\subsubsection{Provedba zaštite podataka i sigurnosti elektroničkih komunikacija}

Sukladno sa Zakonom o elektroničkim komunikacijama, Hrvatska regulatorna agencija za mrežne djelatnosti i Agencija za zaštitu osobnih podataka kao nadležno tijelo za zaštitu osobnih podataka zadužene su za provedbu zaštite podataka i sigurnosti elektroničkih komunikacija ${ }^{43}$ i mogu, u skladu sa svojim ovlastima, po službenoj dužnosti ili na zahtjev zainteresirane strane, odlukom postupati protiv povreda i provoditi nadzor o sigurnosti i zaštiti podataka u elektroničkim komunikacijama, a u skladu s člancima 99. do 107. Zakona o elektroničkim komunikacijama (čl. 107.a ZEK).

\subsubsection{Povreda osobnih podataka u elektroničkim komunikacijama}

U slučaju povrede osobnih podataka operator javno dostupnih elektroničkih komunikacijskih usluga mora bez odgode obavijestiti Hrvatsku agenciju za mrežne djelatnosti - HAKOM (dalje u tekstu: Agencija) i tijelo nadležno za zaštitu osobnih podataka, odnosno Agenciju za zaštitu osobnih podataka (dalje u tekstu: AZOP) o nastaloj povredi. Obavijest mora sadržavati opis posljedica nastale povrede te predložene ili poduzete mjere u svrhu uklanjanja uzroka povrede. Ako je vjerojatno da će nastala povreda osobnih podataka štetno utjecati na osobne podatke ili privatnost korisnika usluga ili druge fizičke osobe, operator javno dostupnih elektroničkih komunikacijskih usluga mora o nastaloj povredi bez odgode obavijestiti i korisnika usluga ili drugu fizičku osobu (čl. 99. a st. 1. ZEK) Operatori javno dostupnih elektroničkih komunikacijskih usluga obvezatni su voditi popis povreda osobnih podataka, koji sadržava činjenice o uzroku povrede osobnih podataka, učincima nastale povrede i poduzetim mjerama zaštite, što omogućuje Agenciji i tijelu nadležnom za zaštitu osobnih podataka provjeru usklađenosti operatora s odredbama ovoga članka. Sadržaj popisa povreda osobnih podataka mora biti ograničen samo na svrhu njegova vođenja (čl. 99. a st. 7. ZEK).

Uredba (EU) br. 910/2014 Europskog parlamenta i Vijeća o elektroničkoj

42 Christine Godt, Regulatory Property Rights: The Transforming Notion of Property in Transnational Business Regulation (Leiden: Brill, 2016.), 79.

43 Marija Boban, Zaštita podataka i pravo na privatnost u informacijskom društvu (Gospić: Veleučilište u Gospiću, 2019.), 105. 
identifikaciji i uslugama povjerenja za elektroničke transakcije na unutarnjem tržištu definirala je sigurnost i zaštitu podataka u elektroničkim komunikacijama kao i interoperabilnost te prekogranični prijenos podataka putem „čvorova“ koji imaju središnju ulogu u međusobnoj povezanosti sustava elektroničke identifikacije država članica. ${ }^{44}$ Njihov je doprinos objašnjen u dokumentaciji povezanoj s Instrumentom za povezivanje Europe uspostavljenim Uredbom (EU) br. 1316/2013 Europskog parlamenta i Vijeća, uključujući funkcije i sastavnice ,čvora eIDAS”. Prema zakonskoj definiciji „čvor” znači mjesto priključenja koji je dio strukture interoperabilnosti elektroničke identifikacije i uključen je u prekograničnu autentifikaciju osoba te ima sposobnost prepoznavanja i obrade, odnosno prosljeđivanja prijenosa na druge čvorove tako što omogućuje da se nacionalna infrastruktura elektroničke identifikacije jedne države članice poveže s nacionalnim strukturama elektroničke identifikacije drugih država članica (čl. 2. st. 1. Uredbe o elektroničkoj identifikaciji). EIDAS čvor (prikazan na slici 1.) je softver koji primjenjuje eIDAS profil i može komunicirati s drugim čvorovima eIDAS mreže. EIDAS čvor može zatražiti (putem eIDAS čvora konektora) ili pružiti (putem usluge eIDAS čvora proxy) prekograničnu provjeru autentičnosti. ${ }^{45}$ Sustav omogućava građanima, tvrtkama i vladama država članica obavljanje prekograničnih elektroničkih transakcija koje se mogu ovjeriti službenim bazama podataka u bilo kojoj zemlji. ${ }^{46}$ Poznat je slučaj ranjivosti eIDAS mreže koje su utvrdile europske vlasti da utječe na programsku podršku eIDAS čvora. Sigurnosni stručnjaci u SEC Consultu izvijestili su o ugroženostima, prva je ranjivost opisana kao lažiranje certifikata (engl. Certificate Faking,) a druga kao izostanak provjere valjanosti certifikata. (engl. Missing Certificate Validation) ${ }^{47} \mathrm{Na}$ temelju toga europska nadležna tijela objavile su sigurnosna ažuriranja za sustav eIDAS (elektronička identifikacija, usluge provjere autentičnosti i povjerenja) kojima su riješili navedene dvije sigurnosne ranjivosti. ${ }^{48}$

44 Provedbena Uredba Komisije (EU) 2015/1501 od 8. rujna 2015. o okviru za interoperabilnost u skladu s člankom 12. stavkom 8. Uredbe (EU) br. 910/2014 Europskog parlamenta i Vijeća o elektroničkoj identifikaciji i uslugama povjerenja za elektroničke transakcije na unutarnjem tržištu, SL L 235/1, 9. 9. 2015. (dalje u tekstu: Uredba o elektroničkoj identifikaciji).

45 Provedbena uredba Komisije (EU) 2015/1502 od 8. rujna 2015. o utvrđivanju minimalnih tehničkih specifikacija i postupaka za razine osiguranja identiteta koje se pripisuju sredstvima elektroničke identifikacije u skladu s člankom 8. stavkom 3. Uredbe (EU) br. 910/2014 Europskog parlamenta i Vijeća o elektroničkoj identifikaciji i uslugama povjerenja za elektroničke transakcije na unutarnjem tržištu, SL L 235/7, 9. 9. 2015.

46 eIDAS eID Profile, pristup 4. siječnja 2020., https://ec.europa.eu/cefdigital/wiki/display/ CEFDIGITAL/eIDAS+eID+Profile.

47 Security affairs, pristup 5. siječnja 2020., https://securityaffairs.co/wordpress/93204/hacking/ eidas-flaws.html.

48 eID Services, pristup 5. siječnja 2020., https://ec.europa.eu/cefdigital/wiki/display/ CEFDIGITAL/All+releases. 


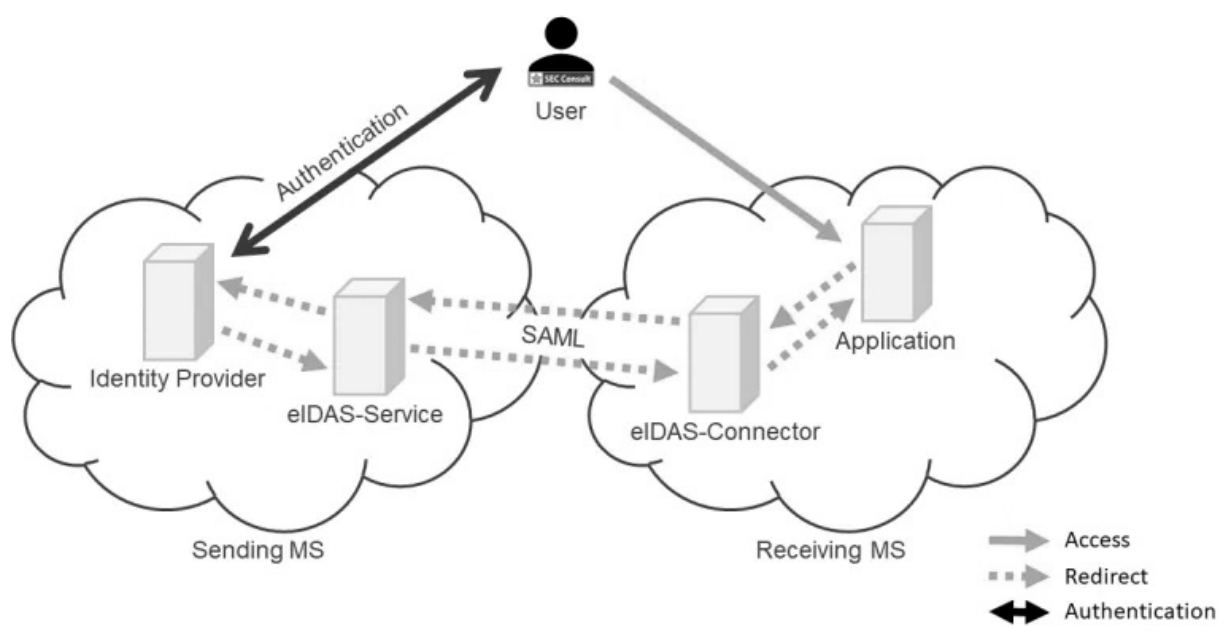

Slika 1. eIDAS sustav (Electronic IDentification, Authentication and trust Services $)^{49}$

\subsubsection{Tajnost elektroničkih komunikacija}

U svrhu osiguravanja tajnosti elektroničkih komunikacija i pripadajućih prometnih podataka $\mathrm{u}$ javnim komunikacijskim mrežama $\mathrm{i}$ javno dostupnim komunikacijskim uslugama, zabranjeno je slušanje, prisluškivanje, pohranjivanje te svaki oblik presretanja ili nadzora elektroničkih komunikacija i pripadajućih prometnih podataka, ${ }^{50}$ osim u slučajevima iz članka 108. ZEK-a te u slučajevima utvrđenima posebnim zakonima (čl. 100. st. 1. ZEK) Zabrana iz stavka 1. ovoga članka ne odnosi se na tehničku pohranu podataka koja je nužna za prijenos komunikacije, pritom ne zadirući u načela zaštite tajnosti podataka (čl. 100. st. 2. ZEK). Odredbe se ZEK-a ne odnose na zakonski ovlašteno bilježenje komunikacija i pripadajućih prometnih podataka tijekom zakonitih poslovnih radnja u svrhu pružanja dokaza o trgovačkim transakcijama ili drugim poslovnim komunikacijama.

\subsubsection{Tajni nadzor elektroničkih komunikacijskih mreža i usluga}

Operatori javnih komunikacijskih mreža i javno dostupnih elektroničkih komunikacijskih usluga te pravne i fizičke osobe, koje na temelju posebnih propisa obavljaju djelatnost elektroničkih komunikacijskih mreža i usluga na području RH, moraju obavljati tu djelatnost te razvijati i upotrebljavati elektroničke komunikacijske mreže i usluge na način koji nije u suprotnosti s nacionalnim interesima u području nacionalne sigurnosti, u skladu sa zakonom kojim je uređen sigurnosno-obavještajni sustav RH. O vlastitom trošku moraju osigurati i održavati funkciju tajnog nadzora

49 Security affairs, pristup 5. siječnja 2020., https://securityaffairs.co/wordpress/93204/hacking/ eidas-flaws.html

50 Andrej Savin, EU Telecommunications Law (Northampton: Edward Elgar Publishing, 2018.), 55 . 
elektroničkih komunikacijskih mreža i usluga, kao i elektroničke komunikacijske vodove do operativno-tehničkog tijela nadležnog za aktivaciju i upravljanje mjerom tajnog nadzora elektroničkih komunikacija.${ }^{51}$ Postupak, kojim se utvrđuje izvršavanje obveza operatora te pravnih i fizičkih osoba, propisuje se zakonom kojim je uređen sigurnosno-obavještajni sustav RH (čl. 108. st. 1. ZEK). Nadležno tijelo prema ZEK-u određuje mjere i standarde informacijske sigurnosti u vezi s obvezama operatora u osiguranju i održavanju funkcije tajnog nadzora elektroničkih komunikacijskih mreža i usluga. U suradnji s tijelima ovlaštenim za primjenu mjera tajnog nadzora elektroničkih komunikacijskih mreža i usluga nadzire provedbu mjera i standarda informacijske sigurnosti, definiranih u ZIS-u. ${ }^{52}$ Operator je obvezatan odrediti osobu odgovornu za provedbu mjera i standarda informacijske sigurnosti (čl. 108. st. 2. ZEK).

\section{UMJESTO ZAKLJUС̆KA}

Vođenje zemljišnih knjiga elektroničkom obradom podataka omogućuje veću transparentnost i publicitet podataka o nekretninama i nositeljima knjižnih prava. Odredbama ZZK-a 2019. jasnije se definiraju ovlaštenici informacijskog sustava te pravo na pristup i pretragu podataka zemljišne knjige elektroničkim putem. Propisana je isključivo e-komunikacija zemljišnoknjižnog suda s tijelima za katastar i drugim tijelima sudbene i upravne vlasti. Propisana je obveza javnih bilježnika da stranke, nakon sastavljanja isprave, solemnizacije i ovjere potpisa na ispravi, upoznaju s mogućnošću podnošenja prijedloga elektronički te da uz njihovu suglasnost prijedlog i dostave zemljišnoknjižnom sudu.

ZZK-a 2019. propisaoje obvezatno prenošenje ulaznih dokumenata u elektronički oblik, kada se za to osiguraju tehnički uvjeti te je uvedena elektronička zbirka isprava. Sve navedeno postupno dovodi do potpunog elektroničkog postupanja u zemljišnim knjigama odnosno do elektroničkog spisa. Nastavlja se razvoj digitalizacije, propisano je prenošenje ručno vođenih zemljišnih knjiga u elektronički oblik, a u planu je i potpuna uspostava digitalne arhive, čime bi se stvorile pretpostavke za uspostavu središnje arhive zemljišnih knjiga svih općinskih sudova na jednom mjestu.

Uspješno provođenje ZZK-a 2019. moglo bi imati postupni prelazak na potpuno elektroničko poslovanje u zemljišnim knjigama. Promjena u organizaciji rada nadležnih tijela u zemljišnoknjižnom sustavu, koji je u cijelosti utemeljen na novim informatičkim tehnologijama, opravdava znatne izmjene zemljišnoknjižnoga zakonodavstva te upućuje na zaključak da ih je radi učinkovite primjene ponuđenih tehnoloških olakšanja neophodno i pravodobno pravno definirati. $\mathrm{Na}$ takvom

51 Marija Boban, „E-privacy regulation - new European framework for regulation on privacy and electronic communications designed to protect user privacy in the digital age", u: Economic and Social Development: 47th International Scientific Conference on Economic and Social Development - Building Resilient Society, eds. Mario Konecki, Irena Kedmenec, Abey Kuruvilla (Zagreb: Varazdin Development and Entrepreneurship Agency, Novosibirsk State University of Economics and Management, University North, 2019.), 177.

52 Wiem Tounsi, Cyber-Vigilance and Digital Trust: Cyber Security in the Era of Cloud Computing and IoT, John (London: Wiley \& Sons, 2019.), 74. 
zamišljenom sustavu potrebno je godinama raditi da se prilagodi zahtjevima i potrebama zakonskog modela te testira njegova funkcionalnost. Uređenje ovih vrlo osjetljivih pitanja zahtijeva posebnu regulativu kojom će se uz poštovanje svih ustavnih načela o zaštiti temeljnih ljudskih prava urediti i odgovarajuća zaštita zemljišnoknjižnih podataka kao osobnih podataka, nadzor nad djelovanjem informatičkog zemljišnoknjižnog sustava te sankcije za zloupotrebu tih podataka. Pred hrvatskim zakonodavcem stoji puno izazova prije nego što zaista počne djelovati optimalno pravno i tehnički uređen EOP zemljišnoknjižni sustav.

\section{LITERATURA}

1. Boban, Marija. „E-privacy regulation - new European framework for regulation on privacy and electronic communications designed to protect user privacy in the digital age". U: Economic and Social Development: 47th International Scientific Conference on Economic and Social Development - Building Resilient Society, eds. Mario Konecki, Irena Kedmenec, Abey Kuruvilla, 176-187. Zagreb: Varazdin Development and Entrepreneurship Agency, Novosibirsk State University of Economics and Management, University North, 2019.

2. Boban, Marija. Zaštita podataka i pravo na privatnost u informacijskom društvu. Gospić: Veleučilište u Gospiću, 2019.

3. Cerrillo Martínez, Agustí et. al. E-Justice: Using Information Communication Technologies in the Court System. Hershey, New York: IGI Global, 2008.

4. Council of Europe. Information Technology and Law: Linking Systems and Their Users: Modern Communication Techniques in the Legal Field: Proceedings. Strasbourg: Council of Europe, 2001.

5. Čizmić, Jozo, Dinka Šago i Blanka Kačer. Osnove zemljišnoknjižnog prava. Maribor: University of Maribor Press, 2018.

6. Čizmić, Jozo, Marija Boban i Dragan Zlatović. Nove tehnologije, intelektualno vlasništvo i informacijska sigurnost. Split: Pravni fakultet Sveučilišta, 2016.

7. eID Services. Pristup 5. siječnja 2020. https:/ec.europa.eu/cefdigital/wiki/display/ CEFDIGITAL/All+releases

8. eIDAS eID Profile. Pristup 5. siječnja 2020. https://ec.europa.eu/cefdigital/wiki/display/ CEFDIGITAL/eIDAS+eID+Profile

9. E savjetovanje. Pristup 20. prosinca 2019. https://esavjetovanja.gov.hr/Econ/ MainScreen?EntityId=9639

10. E savjetovanje. Pristup 21. prosinca 2019. https://esavjetovanja.gov.hr/Econ/ MainScreen?EntityId=11534

11. Godt, Christine. Regulatory Property Rights: The Transforming Notion of Property in Transnational Business Regulation. Leiden: Brill, 2016.

12. Grbac, Mira. „Tranzicija javnobilježničke službe - od tradicije do elektronifikacije“. Javni bilježnik br. 43 (2016): 107-112.

13. Josipović, Tatjana. „Novine u uređenju zemljišnih knjiga”. Pravo u gospodarstvu 35, br. 7-8 (1996): 690-694.

14. Kengyel, Miklós i Zoltán Nemessányi. Electronic Technology and Civil Procedure: New Paths to Justice from Around the World. The Hague: Springer Science \& Business Media, 2012.

15. Končić, Ana-Marija. Novi Zakon o zemljišnim knjigama. pristup 17. prosinca 2019., http:// www.iusinfo.hr/Article/Content.aspx?SOPI=CLN20V01D2019B1306\&Doc $=$ CLANCI HR 
16. Končić, Ana-Marija. Novi Zakon o zemljišnim knjigama - već otvorena pitanja. pristup 21. prosinca 2019., http://www.iusinfo.hr/Article/Content. aspx?SOPI=CLN20V01D2019B1327\&Doc=CLANCI_HR

17. Kontrec, Damir. „Preoblikovanje zemljišne knjige”. U: Osnivanje, obnavljanje, dopunjavanje i preoblikovanje zemljišne knjige, ur. Jerko Slovinić, str. 139 - 156. Zagreb: Novi informator, 2005.

18. Maganić, Aleksandra. „Javni bilježnik u elektroničkom pravnom prometu“. Zbornik radova Pravnog fakulteta u Zagrebu 63, br. 2 (2013): 383-431.

19. Matsuura, Jeffrey H., Security, Rights, and Liabiities in E-Commerce, Artech House, 2001.

20. Matuško Antonić, Ljiljana. „Novela Zakona o zemljišnim knjigama“. Pravo i porezi, br. 12 (2017.), str. 93-99.

21. Milaković, Goran. „Elektroničko poslovanje u zemljišnim knjigama“. Pristup 19. prosinca 2019. http://www.iusinfo.hr/Article/Content.aspx?SOPI $=$ CLN20V01D2017B1069\&Doc $=$ CLANCI_HR

22. Ministarstvo pravosuđa - službene stranice. Pristup 17. prosinca 2019. https://pravosudje. gov.hr/vijesti/projekt-epic-electronic-public-identification-croatia-21403/21403

23. Obrazloženje nacrta prijedloga Zakona o izmjenama i dopunama Zakona o zemljišnim knjigama, Ministarstvo pravosuđa, Zagreb, 2017. Pristup 6. prosinca 2019. https://vlada. gov.hr $>$ UserDocsImages $>$ Sjednice $>2017$

24. Odluka o dopuni odluke o obveznim sudionicima elektroničke komunikacije pred trgovačkim sudovima, Ministarstvo pravosuđa, 14. ožujka 2019. Pristup 9. prosinca 2019. https://pravosudje.gov.hr > UserDocsImages > dokumenti >

25. Pravilnik o elektroničkoj komunikaciji u postupcima pred trgovačkim sudovima, Narodne novine, br. 12/18.

26. Pravilnik o elektroničkom poslovanju korisnika i ovlaštenih korisnika sustava zemljišnih knjiga, Narodne novine, br. 108/19.

27. Pravilnik o unutarnjem ustroju, vođenju zemljišnih knjiga i obavljanju drugih poslova u zemljišnoknjižnim odjelima sudova, Zemljišnoknjižni poslovnik, Narodne novine, br. 81/97., 109/02., 123/02., 153/02., 14/05. i 60/10.

28. Pravilnik o tehničkim i drugim uvjetima elektroničkog poslovanja u zemljišnim knjigama, Narodne novine, br. 119/15., 23/17. i 106/18.

29. Provedbena Uredba Komisije (EU) 2015/1501 od 8. rujna 2015. o okviru za interoperabilnost u skladu s člankom 12. stavkom 8. Uredbe (EU) br. 910/2014 Europskog parlamenta i Vijeća o elektroničkoj identifikaciji i uslugama povjerenja za elektroničke transakcije na unutarnjem tržištu, SL L 235/1, 9. 9. 2015.

30. Provedbena uredba Komisije (EU) 2015/1502 od 8. rujna 2015. o utvrđivanju minimalnih tehničkih specifikacija i postupaka za razine osiguranja identiteta koje se pripisuju sredstvima elektroničke identifikacije u skladu s člankom 8. stavkom 3. Uredbe (EU) br. 910/2014 Europskog parlamenta i Vijeća o elektroničkoj identifikaciji i uslugama povjerenja za elektroničke transakcije na unutarnjem tržištu, SL L 235/7, 9. 9. 2015.

31. Ružička, Bruno „Stanje digitalne zemljišne knjige realnost ili tlapnja“. Pravo $u$ gospodarstvu 57, br. 1 (2018): 145-163.

32. Savin, Andrej. EU Telecommunications Law. Northampton: Edward Elgar Publishing, 2018.

33. Security affairs. Pristup 5. siječnja 2020. https://securityaffairs.co/sordpress/93204/ hacking/eidas-flaws.html

34. Shaw, Paul. Managing Legal and Security Risks in Computers and Communications. Boston: Butterworth-Heinemann, 1998.

35. Šago, Dinka. „Zabilježba prvenstvenog reda u zemljišnim knjigama“, u: Zbornik radova s III. međunarodnog savjetovanja „Aktualnosti građanskog procesnog prava-nacionalna i usporedna pravnoteorijska i praktična dostignuća“, ur. Dinka Šago et al., 275-297. Split: Sveučilište u Splitu Pravni fakultet, 2017. 
36. Šago, Dinka i Marija Boban. "Neki aspekti novina u elektroničkoj komunikaciji pred sudovima", Zbornik radova s V. međunarodnog savjetovanja Aktualnosti građanskog procesnog prava - nacionalna i usporedna pravnoteorijska i praktična dostignuća, ur. Dinka Šago et al. 471-497. Zagreb: Pravni fakultet Split, 2019.

37. Šago, Dinka i Zrinka Radić. „Brisovna tužba - zaštita knjižnih prava“. Zbornik Pravnog fakulteta Sveučilišta u Rijeci 38, br. 1 (2017.): 475-499.

38. Tounsi, Wiem. Cyber-Vigilance and Digital Trust: Cyber Security in the Era of Cloud Computing and IoT. London: John Wiley \& Sons, 2019.

39. Turković, Marina. „E-upis u zemljišne knjige putem javnih bilježnika”. Pristup 21. prosinca 2019. http://www.iusinfo.hr/DailyContent/Topical.aspx?id=30288

40. Vrcić, Ivana. „Mogući aspekti zaštite stranaka u pravnom prometu nekretnina širenjem javnobilježničke nadležnosti““. Javni bilježnik br. 43 (2016): 99-105.

41. Wudarski, Arkadiusz i Tatjana, Josipović. „Kompjutorizacija u poljskom i hrvatskom pravu", Zbornik Pravnog fakulteta u Zagrebu 65, br. 1 (2015): 5-54.

42. Zakon o elektroničkim komunikacijama, Narodne novine, br. 73/08., 90/11., 133/12., 80/13., 71/14., 72/17.

43. Zakon o informacijskoj sigurnosti, Narodne novine, br. 79/07.

44. Zakon o izmjenama i dopunama Zakona o parničnom postupku, Narodne novine, br. $70 / 19$.

45. Zakon o tajnosti podataka, Narodne novine br. 79/07., 86/12.

46. Zakon o zemljišnim knjigama, Narodne novine, br. 63/19.

47. ZIS - Zajednički informacijski sustav zemljišnih knjiga i katastra. Pristup 8. prosinca 2019. https://oss.uredjenazemlja.hr/public/index.jsp 


\author{
Dinka Šago* \\ Marija Boban**
}

Summary

\title{
THE IMPORTANCE OF ELECTRONIC COMMUNICATION IN COURT PROCEEDINGS WITH SPECIAL REFERENCE OF LAND REGISTER PROCEDURES
}

In this article the authors explore the topic of the use of information and communication technologies and electronic communication in court proceedings while giving an overview of the existing legislative framework governing this area with an analysis of their impact on the increasing scope of electronic business. The use of electronic data processing in the land register system is certainly a very demanding process not only in sense of financial, security question and technical sense, but also in the area of legal regulation of the process of electronic identification and conversion of land register in the electronic form. The paper outlines the most significant novelties enacted by the Land Registry Act in the year 2019 regarding the electronic operation of the electronic land register, as well as an overview of the provisions of the new Rulebook on electronic business of users and authorized users of the land registry system. The electronic processing of land registry data, and in particular rules on unrestricted access to land registry data through electronic communications, raises a number of issues of establishing an optimal balance in the protection of citizens interests and rights, and in particular the protection of electronic registry and citizens personal data. Unrestricted access to electronic land register contributes to a greater security of legal transactions and greater protection of enrolled holders of legal rights. On the other hand, it raises significant questions regarding the protection of constitutionally guaranteed constitutional rights.

Keywords: land registry database; electronic communication; information security; electronic land register; common information system.

\footnotetext{
* Dinka Šago, Ph.D., Associate Professor, Faculty of Law, University of Split; dinka.sago@ pravst.hr.

** Marija Boban, Ph.D., Associate Professor, Faculty of Law, University of Split; marija.boban@ pravst.hr.
} 


\section{Zusammenfassung}

\section{ELEKTRONISCHE KOMMUNIKATION IN GERICHTSVERFAHREN MIT BESONDERER BERÜCKSICHTIGUNG DER GRUNDBUCHVERFAHREN}

In diesem Beitrag bearbeiten die Autorinnen das Thema der Benutzung der Informations- und Kommunikationstechnologie und elektronischen Kommunikation in Gerichtsverfahren, indem sie die Übersicht des bestehenden Gesetzesrahmens für diesen Bereich anbieten und sein Einfluss auf den steigenden Umfang des E-Business analysieren. Die Einführung elektronischer Datenbearbeitung in das Grundbuchsystem ist jedenfalls ein sehr anspruchsvoller Prozess nicht nur im finanziellen, sicherheitsbezogenen und technologischen Sinne, sondern auch bei der rechtlichen Regelung sowohl der elektronischen Identifizierung als auch der Grundbuchführung in elektronischer Form. Der Beitrag bespricht die von der Grundbuchordnung von 2019 eingeführten bedeutendsten Neuigkeiten sowie auch die Übersicht der Bestimmungen der neuen Regelung über E-Business der Benutzer und befugten Benutzer des Grundbuchsystems. Elektronische Führung von Grundbuchdaten und insbesondere die Regeln über unbeschränkte Einsicht in die Grundbuchdaten mittels Netzkommunikationen öffnen eine ganze Reihe von Fragen über die Erzielung optimalen Gleichgewichts beim Schutz bestimmter Interessen und Rechte und vor allem beim Schutz von Daten und personenbezogenen Daten von Bürgern. Eine unbeschränkte Einsicht in die Grundbuchdaten bring der größeren Sicherheit des rechtlichen Verkehrs, dem Vertrauensschutz sowie auch dem höheren Schutz von eingetragenen Berechtigten im Grundbuch bei.

Schlüsselwörter: Grundbuchdatenbasis; elektronische Kommunikation; elektronisches Grundbuch (EOP); Informationssicherheit; gemeinsames Informationssystem.

Riassunto

\section{L'IMPORTANZA DELLA COMUNICAZIONE ELETTRONICA NEI PROCESSI GIUDIZIARI CON PARTICOLARE RIFERIMENTO ALLE PROCEDURE TAVOLARI}

Nell'articolo le autrici esplorano il tema dell'uso di tecnologie dell'informazione e della comunicazione, come anche delle comunicazioni elettroniche nei processi giudiziari, fornendo una mappatura del quadro legislativo positivo esistente in quest'area con un'analisi circa il loro impatto sulla crescita dello svolgimento di 
attività commerciali per vie elettroniche. L'introduzione dell'elaborazione elettronica dei dati nel sistema tavolare è sicuramente un processo complesso non solo da un punto di vista finanziario, della sicurezza e tecnologico, ma pure sotto il profilo della disciplina legale del processo d'identificazione elettronica e dalla conversione dei libri fondiari in forma elettronica. Questo lavoro sottolinea le modifiche più significanti introdotte dall'emendamento della Legge sui libri fondiari nel 2019 riguardo alle operazioni elettroniche nel registro tavolare elettronico ed illustra anche le disposizioni del nuovo Regolamento sulle attività commerciali elletroniche degli utenti e degli utenti autorizzati del sistema tavolare. Dalla tenuta elettronica del registro tavolare, in particolare dalle regole sull'accesso illimitato ai dati del registro tavolare tramite comunicazioni elettroniche, emergono numerosi problemi circa l'equilibrio ottimale nella protezione dei diritti e degli interessi dei cittadini, particolarmente la protezione dei registri elettronici e dei dati personali dei cittadini. L'accesso illimitato al registro tavolare elettronico contribuisce ad innalzare il grado di sicurezza della circolazione giuridica, come pure il livello di protezione dei titolari dei diritti intavolati. D'altra parte si apre la significante questione riguardante la protezione dei diritti costituzionali garantiti dalla Costituzione stessa in capo ai titolari dei diritti tavolari.

Parole chiave: base dei diritti tavolari; comunicazione elettronica; sicurezza delle informazioni; registro tavolare elettronico; sistema comune di informazioni. 